\title{
UWAGI O TYMCZASOWYM I DEFINITYWNYM NASTĘPSTWIE ZASTOSOWANIA KONSTRUKCJI NADUŻYCIA PRAWA PODMIOTOWEGO
}

Wydawać by się mogło, że stanowiąca jedną z najważniejszych przejawów pierwiastka słusznościowego $\mathrm{w}$ dziedzinie stosunków cywilnoprawnych problematyka nadużycia prawa podmiotowego (art. 5 k.c.) przy obecnym stanie piśmiennictwa i orzecznictwa nie pozostawia pola do prowadzenia rozważań choćby w niewielkim stopniu nieodtwórczych - doczekała się wszak już wielu opracowań doktrynalnych, obrosła też pokaźnym dorobkiem judykatury. Zainteresowaniu owym przejawem problematyki słusznościowej w prawie nie ma co się zresztą dziwić, gdyż problematyka konsekwencji wykonywania praw podmiotowych w sposób nieakceptowalny społecznie, mając na uwadze funkcjonujące i uznane powszechnie normy moralne oraz oceny będące dla ich sformułowania podstawą, należy do najbardziej podstawowych zagadnień prawoznawstwa, jak i szczegółowych nauk prawnych.

Nie zamierzam przedstawiać tu szczegółowo teoretycznych, dobrze znanych i zasadniczo satysfakcjonująco scharakteryzowanych w piśmiennictwie i orzecznictwie elementów konstrukcyjnych regulacji art. 5 k.c., zgodnie z którym wykonywanie prawa w sposób sprzeczny ze społeczno-gospodarczym przeznaczeniem prawa i zasadami współżycia społecznego ${ }^{1}$ nie korzysta $z$ ochrony. Truizmem jest twierdzenie, że w polskim prawodawstwie przyjęto tzw. wewnętrzną koncepcję nadużycia prawa podmiotowego, ${ }^{2}$ a więc zachowanie podjęte $w$ tych warunkach nie uznaje się w ogóle za wykonywanie prawa. W związku z konstrukcją przyjętą w art. 5 k.c.

1 A więc, jak stwierdził Sąd Najwyższy w wyroku z dnia 23.05.2013 r., sygn. IV CSK 660/12 (Lex nr 1365725), a wcześniej w wyroku z dnia 4.10.2001 r., sygn. I CKN 458/00 (LEX nr 52717), w sposób sprzeczny w istocie z zasadami słuszności, dobrej wiary w znaczeniu obiektywnym czy też zasad uczciwości obowiązujących w stosunkach cywilnoprawnych. W wyroku z dnia 2.06.2011 r., sygn. I CSK 520/10 (LEX nr 1129076) Sąd Najwyższy wprost stwierdza się, że zasady współżycia społecznego są obecnie często określane zasadami słuszności. A. Bierć wprost wskazuje, że w art. 5 k.c. sformułowano zakaz wykonywania praw podmiotowych w sposób naruszający reguły słuszności (zob. A, Bierć, Zarys prawa prywatnego. Część ogólna, Warszawa 2012, s. 115). Zamiast wielu: T. Justyński, Nadużycie prawa w polskim prawie cywilnym, Kraków 2000, s. 55 i n. 
formułuje się pewne podstawowe wymogi stosowania art. 5 k.c., ${ }^{3}$ takie jak zasada czystych rąk, ${ }^{4}$ obronny charakter zarzutu ${ }^{5}$ nadużycia prawa (które nie może stanowić samodzielnej podstawy powództwa ani podstawy nabycia prawa podmiotowego ${ }^{6}$ ) oraz reguły, zgodnie z którą na podstawie art. 5 k.c. nie może dojść do utraty prawa podmiotowego. ${ }^{7}$ Oczywiście pomimo tego, że sformułowanie tych zasad jest, jeśli chodzi o samo ujęcie kierunkowe, dość niekontrowersyjne, to przy ich dookreśleniu, czy też precyzyjnym określeniu ich sposobu rozumienia występują pewne rozbieżności u poszczególnych autorów. ${ }^{8}$

Jedną z fundamentalnych właściwości przypisywanych owej konstrukcji jest również zasadniczo prowizoryczny, tymczasowy skutek wykonywania prawa podmiotowego w sposób sprzeczny z zasadami współżycia społecznego. I tak, R. Trzaskowski i S. Dmowski stwierdzają, ,przepis ten może jedynie pozbawić prawo podmiotowe ochrony przez pewien czas. Osoba, której przysługuje określone prawo podmiotowe może $\mathrm{z}$ niego skorzystać w razie zmiany sytuacji faktycznej, nawet w sytuacji, gdy uprzednio wniesione przez nią powództwo zostało oddalone z powodu sprzeczności żądania z zasadami współżycia społecznego (...). Powód, wytaczając nowe (ponowne) powództwo, powinien zgłosić i uzasadnić twierdzenie, że stan faktyczny uległ tak istotnej zmianie, iż w obecnej chwili jego żądanie nie jest już sprzeczne z zasadami współżycia społecznego". 9 A. Doliwa stwierdza, że ,„przepis art. 5 k.c. może pozbawić prawo podmiotowe ochrony jedynie przez pewien czas. Osoba, której przysługuje określone prawo podmiotowe, może z niego skorzystać w razie zmiany okoliczności faktycznych, które w uprzednim momencie uzasadniały zarzut nadużycia prawa”. ${ }^{10}$ P. Machnikowski wskazuje zaś: „okoliczności nakazujące uznać powoda za nieuprawnionego mają charakter przejściowy; po ich

Por. przykładowo A. Zbiegień-Turzańska, (w:) Kodeks cywilny. Komentarz, tom I, pod red. K. Osajdy, Warszawa 2013, s. 326 in.

$4 \quad$ Ostatnio zob. wyrok SN z dnia 12.06.2013 r., sygn. II CSK 632/11, LEX nr 1353432

$5 \quad$ Nie budzi wątpliwości, że stan nadużycia prawa sąd powinien brać pod uwagę z urzędu, nie zaś jedynie na zarzut strony. W niniejszym artykule pisząc o zarzucie nadużycia prawa mam na myśli sam stan nadużycia prawa, zaś sformułowanie „zarzut” stosowane jest dlatego, że jego użycie jest powszechne dla samego wskazania, że właśnie ze stanem nadużycia prawa mamy do czynienia, zasadniczo abstrahując od tego, z czyjej inicjatywy stwierdza się jego zaistnienie.

$6 \quad$ Zob. przykładowo wyrok SN z dnia 11.07.2012 r., sygn. II CSK 677/11, LEX nr 1228438.

7 Jakkolwiek ta reguła bywa stawiana w jednym szeregu z zakazem pozbawiania na podstawie art. 5 praw podmiotowych.

8 Jak choćby, przykładowo, pojmowanie zasady czystych rąk - w orzecznictwie nieraz można spotkać się z prezentowaniem w prostej zależności - kto pozostaje w kolizji z zasadami współżycia społecznego nie korzysta z ochrony. W literaturze przedstawiana zaś jest nieraz nieco bardziej zniuansowana wersja tej zasady, zgodnie którą należy brać pod uwagę całokształt okoliczności danego przypadku, zaś reguła ta wskazuje raczej na pożądany kierunek, w którym powinno się podążać przy ocenie, czy doszło do nadużycia prawa wyważając interesy obu podmiotów (zob. A. Wolter, J. Ignatowicz, K. Stefaniuk, Prawo cywilne. Zarys części ogólnej, Warszawa 2001, s. 153; M. Pyziak-Szafnicka, (w:) System prawa prywatnego. Prawo cywilne - część ogólna, t. 1, pod red. M. Safjana, Warszawa 2007, s. 819. Doprecyzowywane bywają konsekwencje reguły, zgodnie z którą nie można na tle art. 5 k.c. mówić o samodzielnej podstawie powództwa; zob. A. Wolter, J. Ignatowicz, K. Stefaniuk, Prawo cywilne..., op. cit., s. 153-154; P. Machnikowski, (w:) Kodeks cywilny. Komentarz, pod red. E. Gniewka i P. Machnikowskiego, Warszawa 2013, s. 21-22.

9 S. Dmowski, R. Trzaskowski (w:) Kodeks cywilny. Komentarz. Część ogólna, t. I, pod red. J. Gudowskiego, Warszawa 2013, s. 54.

10 A. Doliwa, Prawo cywilne - część ogólna, Warszawa 2010, s. 64. 
ustaniu będzie on mógł swoje uprawnienie realizować. Dlatego wyrok oddalający powództwo, oparty na art. 5 k.c. praktycznie nie korzysta z powagi rzeczy osądzonej - jeśli powód twierdzi, że okoliczności te uległy zmianie, możliwe jest prowadzenie kolejnego procesu pomiędzy tymi samymi stronami o to samo roszczenie, a jeżeli twierdzenie o zmianie okoliczności okaże się prawdziwe - uwzględnienie powództwa". ${ }^{11}$ Podobnie rozważany aspekt charakteryzują A. Brzozowski, W. Kocot i E. Skowrońska-Bocian wskazując, że wykonywanie prawa podmiotowego w sposób sprzeczny z klauzulami zawartymi w art. 5 k.c. „(...) pociąga za sobą odmowę udzielenia ochrony realizowanemu prawu. (...) Skorzystanie ponownie z uprawnień przez uprawnionego jednak w innych okolicznościach, może (...) okazać się wykonywaniem prawa w sposób godny ochrony (...)". ${ }^{12}$ Z kolei Z. Radwański oraz A. Olejniczak, opisując wpływ kontekstu społecznego na możliwość realizacji prawa podmiotowego zauważają, że ,kontekst ten może się jednak w przyszłości zmienić i wówczas klauzule generalne art. 5 k.c. nie będą tamowały realizacji prawa podmiotowego". 13

Z kolei w orzecznictwie Sądu Najwyższego aspekt tymczasowości skutku zarzutu nadużyci prawa charakteryzuje się wskazując, że ,art. 5 k.c. dotyczy sytuacji, gdy stosunek prawny już istnieje $\mathrm{i}$ istniejące uprawnienie wchodzące w skład jego treści jest ważne, ale w trakcie trwania tego stosunku prawnego zaszły takie nowe okoliczności, które w świetle zasad współżycia społecznego przeciwstawiają się dochodzeniu uprawnienia tak długo, dopóki będą trwały te okoliczności."14 W uzasadnieniu wyroku z dnia 19 lutego 1999 r. ${ }^{15} \mathrm{SN}$ zawarł stwierdzenie, zgodnie z którym „zastosowanie art. 5 k.c. nie może doprowadzić do utraty prawa, a tylko pozbawić prawa przez pewien czas ochrony".

Tak pojmowaną zasadą tymczasowego, prowizorycznego jedynie skutku, który pociąga za sobą stan nadużycia należy widzieć w kontekście innych wzmiankowanych reguł konstrukcyjnych art. 5 k.c., w szczególności mówiących o niedopuszczalności utraty ${ }^{16}$ ani nabycia prawa podmiotowego na jego podstawie. Nietrwałości skutków nadużycia prawa nie należy - mając na uwadze samą konstrukcję regulacji nadużycia prawa - ujmować w kategorii koniecznej, nieuchronnej konsekwencji założenia o niedopuszczalności utraty prawa podmiotowego. Można wszak hipotetycznie wyobrazić sobie takie ukształtowanie regulacji nadużycia prawa, w ramach którego - wskutek nadużycia prawa - przy formalnym utrzymaniu statusu podmiotu prawa traci się możliwość jego wykonywania definitywnie, co w istocie sprawia, że uprawnionemu przysługiwałby jedynie nie wypełniony jakąkolwiek rzeczywistą

\footnotetext{
11 P. Machnikowski, (w:) Kodeks cywilny. Komentarz, s . 22-23.

12 A. Brzozowski, W. Kocot, E. Skowrońska-Bocian, Prawo cywilne. Część ogólna, Warszawa 2010, s. 181.

13 Z. Radwański, A. Olejniczak, Prawo cywilne - część ogólna, Warszawa 2012, s. 107.

14 Tak Sąd Najwyższy w wyroku z dnia 5.03.2002 r., sygn. I CKN 934/00, LEX nr 54371, identycznie w wyroku z dnia 9.01.2004 r., sygn. IV CK 338/02, Lex nr 520026

15 Sygn. akt II CKN 200/98, LEX nr 1212963.

16 Zob. T. Justyński, Nadużycie prawa w polskim prawie cywilnym, Kraków 2000, s. 138 i n.
} 
treścią tytuł prawny (nudum ius). ${ }^{17}$ Jednak - patrząc od drugiej strony - koniecznym następstwem ukształtowania regulacji nadużycia prawa w oparciu o założenie nietrwałości skutku nadużycia prawa rozumianego jedynie jako brak możliwości jego realizacji w okresie istnienia pewnych okoliczności jest uznanie, że nie można w ten sposób utracić (odnosząc to do osoby nadużywającej prawo) ani nabyć (w odniesieniu do osoby, do której odnosi się czynienie użytku z prawa w takich warunkach) prawa podmiotowego. ${ }^{18}$

Należy jednak zauważyć, że założenie o przejściowym skutku stanu nadużycia prawa nie jest skrajnie absolutyzowane w piśmiennictwie, orzecznictwo Sądu Najwyższego również nie jest w pełni konsekwentne w tym zakresie. Przede wszystkim wskazać należy, że o ile w rozważaniach doktrynalnych, których głównym przedmiotem jest problematyka art. 5 k.c., wyraźnie akcentuje się tę zasadę, ${ }^{19}$ to $\mathrm{w}$ przypadkach, gdy art. 5 k.c. stanowi jedynie jedną z wielu kwestii (niekiedy poboczną, wpadkową) w toku prowadzonych rozważań, nieraz proponuje się jego zastosowanie nie bacząc na zgodność takiej propozycji z modelowymi przesłankami zastosowania art. 5 k.c. ${ }^{20}$ Można również przywołać wyrażoną w piśmiennictwie opinię (w odniesieniu do oddalenia roszczenia windykacyjnego z powołaniem się na nadużycie prawa), że prowizoryczność stanu nadużycia prawa jest swego rodzaju mitem; innymi słowy, założenie, że w konsekwencji zastosowania art. 5 k.c. dochodzi do ukształtowania jedynie tymczasowego skutku w zakresie niemożności korzystania $\mathrm{z}$ uprawnienia nie jest poprawne, ponieważ zależy to od dalszego rozwoju

17 Chodzi o czysto teoretyczną możliwość takiego ukształtowania owego rozwiązania prawnego abstrahując od uwarunkowań na tle konkretnego systemu prawa, w szczególności jego zgodności z konstytucją, zob. W. Borysiak, Ochrona własności a nadużycie prawa, „Studia luridica” 2009, nr 52, s. 23. Por. również co do konsekwencji trwałości stanu powstałego wskutek zachowania uprawnionego w warunkach art. 5 k.c. T. Justyński, Nadużycie prawa..., op. cit., s. 140.

18 Jeśli więc przyjąć, że owa nietrwałość sytuacji nadużycia prawa jest esencjalnym elementem tej konstrukcji prawnej, nie dość precyzyjną charakterystyką owego uregulowania - przy pominięciu aspektu nietrwałości - jest ograniczenie się do stwierdzenia, że art. 5 nie może być podstawą nabycia ani utraty prawa podmiotowego; tak jednak zwłaszcza w dawniejszym piśmiennictwie S. Szer, Prawo cywilne. Część ogólna, Warszawa 1967, s. 138, Omawiany aspekt nietrwałości skutków nadużycia prawa nie jest również szczególnie uwypuklany przez A. Woltera, J, Ignatowicza i K. Stefaniuka, zob. tychże, Zarys..., op. cit., s. 154.

19 Jakkolwiek nie zawsze nadając jej taką samą rangę. Przykładowo jest ona szczególnie mocno i konsekwentnie uwypuklana przez T. Justyńskiego (por. glosy jego autorstwa przywoływane w dalszej części niniejszego artykułu), z kolei M. Pyziak-Szafnicka respektując ją, nie absolutyzuje. Kwestia ta zostanie rozwinięta w dalszej części artykułu.

20 Spośród nowszych publikacji zob. M. Dumkiewicz, Skutki braku kontrasygnaty skarbnika gminy na tle sankcji wadliwych czynności prawnych, „Przegląd Prawa Handlowego” 2013, nr 9, s. 52, która stwierdza, na tle art. 46 ustawy z dnia 8.03.1990 r. o samorządzie gminnym (Dz.U. z 2013 r. poz. 594 z późn. zm.), że w razie dokonania czynności bez kontrasygnaty skarbnika i wykonania świadczenia przez kontrahenta gminy, gdy ów kontrahent żąda od gminy spełnienia świadczenia wzajemnego, powoływanie się przez gminę na nieskuteczność umowy byłoby sprzeczne z art. 5 k.c. Uzasadnienia dla takiego rezultatu należałoby raczej poszukiwać (nie rozstrzygając tu o jego poprawności dogmatycznej) w odpowiedniej, funkcjonalnej wykładni przywołanego przepisu ustawy o samorządzie gminnym, nie zaś przez odwoływanie się do art. 5 z tej przyczyny, że po pierwsze, mamy do czynienia $z$ osiągnięciem rezultatu polegającego $\mathrm{w}$ istocie na zastąpieniu $\mathrm{w}$ ten sposób przesłanki powstania skutków prawnych wymaganej wprost przez ustawę i „uskutecznieniu” na jego podstawie roszczenia strony umowy - tym samym - osiągnięcie efektu w żadnym razie nie tymczasowego. Poza tym, chodzi o pewną stypizowaną kategorię przypadków, nie zaś o konkretny przypadek uzasadniony szczególnymi, zindywidualizowanymi okolicznościami, co dyskwalifikuje zastosowanie art. 5 k.c. 
okoliczności faktycznych. ${ }^{21}$ Czynienie tego rodzaju zarzutu nie jest jednak uzasadnione, ponieważ możliwość wystąpienia trwałych następstw w wyniku nadużycia prawa jest wpisana $\mathrm{w}$ tę konstrukcję prawną, nie zaś czynnikiem wskazującym na jej niepoprawność. Przede wszystkim wypada wskazać, że skutek tymczasowy jest to typowy skutek zastosowania konstrukcji nadużycia prawa. W wypadkach szczególnych rezultat ten może ukształtować się inaczej, co jednak samo w sobie nie świadczy o wadliwości, czy też niekonsekwencji w konstrukcji poglądu dominującego. Ponadto, samo ujęcie poglądu dominującego w ten sposób, jakoby w każdym przypadku zastosowania konstrukcji nadużycia prawa musielibyśmy mieć do czynienia z prowizorycznością jego skutku (co wydaje się czynić Autorka) nie jest właściwe. W rzeczywistości akcent położony być powinien na inny aspekt tak rozumianego nietrwałego skutku podniesienia zarzutu nadużycia prawa, który scharakteryzować można w ten sposób, że nie zakłada się z góry, ale też i nie wyklucza trwałości konsekwencji działania w warunkach nadużycia prawa. $Z$ takiego ujęcia nie wynika, że definitywnie w każdej sytuacji, w której stosując prawo odwołano by się do konstrukcji z art. 5 k.c. wykluczone byłyby a limine trwałe konsekwencje takiego stanu. Stwierdzeniu temu towarzyszy jednak założenie, że okoliczności towarzyszące wykonywaniu prawa podmiotowego mają generalnie zmienny charakter i nie sposób zasadniczo przewidzieć, jak (i czy) się zmienią w przyszłości. ${ }^{22} \mathrm{~W}$ praktyce, o ile nie ma się na myśli przeszłych zdarzeń bez rozważania ich implikacji w teraźniejszości ani w przyszłości, trudno mówić o stałości okoliczności faktycznych, są one z zasady potencjalnie zmienne ${ }^{23}$ Sąd stosując art. 5 k.c. nie może więc z góry określić przedziału czasowego, w którym prawo podmiotowe nie będzie mogło być wykonywane. ${ }^{24}$

Odpierając wątpliwości podnoszone przez Autorkę postawiono także zarzut, że nie tyle zastosowanie przez sąd prowadzi do trwałego skutku stanu nadużycia prawa, ale brak zmiany okoliczności faktycznych. ${ }^{25}$ Trudno zaprzeczyć precyzji tego spostrzeżenia, jednak należy mieć na uwadze, że w istocie Autorce chodziło raczej o rozbieżność między deklaratywnie przyjmowaną w orzecznictwie i piśmiennictwie koncepcją nadużycia prawa a rzeczywistymi skutkami stosowania art. 5 k.c., nie zaś o ścisłe określenie źródła trwałości skutków stanu nadużycia prawa w ramach konkretnej konstrukcji prawnej nadużycia prawa.

Inną perspektywę trwałego i tymczasowego charakteru odmowy ochrony wykonania prawa podmiotowego prezentuje R. Trzaskowski. Ów autor zwrócił mianowicie uwagę na to, że w praktyce orzeczniczej Sądu Najwyższego wskazać można

Tak A. Zbiegień, Glosa do wyroku Sądu Najwyższego z dnia 6.01.2006 r., sygn. III CK 129/04, „Palestra” 2006, nr 9-10, s. 306.

22 Tak słusznie - odnosząc się do obiekcji zgłoszonych przez A. Zbiegień, W. Borysiak, Ochrona własności..., op. cit., s. 37. 
na rozstrzygnięcia w istocie sankcjonujące trwały skutek zastosowania art. 5 k.c. W tym kontekście odwołał się przykładowo do wyroków Sądu Najwyższego, w których uznawano za nadużycie prawa żądanie zapłaty opłaty rocznej z tytułu użytkowania wieczystego za okres po jego wygaśnięciu, gdzie okoliczności uzasadniające sięgnięcie do regulacji art. 5 k.c. miały niezmienny charakter. Autor uznał, że przyjęcie jedynie tymczasowego skutku zastosowania art. 5 k.c. nie ma wystarczających racji celowościowych. ${ }^{26}$ Wprost przeciwnie - racje celowościowe wespół z argumentacją mającą za podstawę literalną wykładnię tego przepisu - uzasadniają raczej przyjęcie, że jeśli czynienie użytku z prawa jest trwale sprzeczne z zasadami słuszności, to również na trwale uprawniony zostanie pozbawiony ochrony i należy liczyć się z tym, że w praktyce może to doprowadzić do powstania stanu równoważnego z utratą (redukcją) prawa. ${ }^{27}$ Przy tym Autorowi chodzi o okoliczności w tym sensie trwałe, że ich immanentną cechą jest to, że już „na wstępie” wskazują na swój niezmienny charakter, ${ }^{28}$ okoliczności pozostające niejako „obok”, niezależne od innych potencjalnie zmiennych elementów stanu faktycznego, w którym dochodzi do nadużycia prawa. Przy tym owe okoliczności w przeciwieństwie do innych elementów tego stanu faktycznego nie podlegają zmianie (nie mogą podlegać zmianie z istoty), stąd nie da się tu mówić o ewentualności zmiany powodującej możliwość wykonywania prawa. ${ }^{29}$ Jak w przypadku orzeczenia dotyczącego opłaty za użytkowanie wieczyste - chodzić może o ujemną ocenę aksjologiczną będącą w sumie pochodną determinowanych normatywnie okoliczności związanych z realizacją uprawnienia. ${ }^{30}$ Wydaje się, że może chodzić również o dezaprobowane (ujemnie oceniane)

R. Trzaskowski, Możliwość stosowania art. 5 k.c. w przypadkach, w których okoliczności uzasadniające zarzut nadużycia prawa mają charakter trwały, „Palestra” 2010, nr 1-2, s. 252-253; idem, Skutki sprzeczności umów obligacyjnych z prawem, Warszawa 2014, s. 482.

27 R. Trzaskowski, Możliwość stosowania..., op. cit., s. 252-253.

28 W kontekście rozstrzygnięć Sądu Najwyższego dotyczących opłaty rocznej za okres po wygaśnięciu użytkowania wieczystego, w wyroku z dnia 15 lutego 2002 r., sygn. V CA 2/02, OSNC 2003 nr 1 poz. 12 Sąd Najwyższy odwołał się do argumentacji ewidentnie świadczącej o trwałym skutku nadużycia prawa na gruncie danej sprawy: „Opłata roczna, należna od użytkownika wieczystego, jest pewnego rodzaju ekwiwalentem za korzystanie z cudzej nieruchomości w sposób określony umową o ustanowieniu prawa użytkowania wieczystego, natomiast opłata za przekształcenie prawa użytkowania wieczystego w prawo własności jest wynagrodzeniem za przeniesienie własności nieruchomości gruntowej w szczególny sposób, przewidziany ustawą z dnia 4 września 1997 r. Wynagrodzenie to służy zrekompensowaniu dotychczasowemu właścicielowi (Skarbowi Państwa lub gminie) utraty przysługującego mu do nieruchomości gruntowej prawa własności oraz utraty stałego dopływu kwot z tytułu opłaty rocznej za użytkowanie wieczyste. Obydwa te cele, spełniane przez opłatę należną z tytułu przekształcenia, wyrównują całkowicie uszczerbek dotychczasowego właściciela gruntu, powstały w następstwie utraty przezeń prawa własności nieruchomości wskutek uwłaszczenia dotychczasowego użytkownika wieczystego, domaganie się zatem jeszcze opłaty za użytkowanie wieczyste, i to za okres, w którym pozwany był już właścicielem, jest więc nieuzasadnione." Niczego w tej mierze nie zmieniają zawarte w uzasadnieniu wyroku deklaracje, że owo rozstrzygnięcie nie skutkuje pozbawieniem właściciela nieruchomości przysługującego mu uprawnienia, ponieważ w istocie przysługiwałoby mu to uprawnienie jedynie formalnie bez możliwości jego realizacji.

29 Obok sytuacji wskazanych w wymienianych tu opracowaniach R. Trzaskowskiego należy wskazać na analizowane w dalszej części niniejszego artykułu judykaty sądów apelacyjnych dotyczące obniżenia na podstawie art. 5 k.c. wysokości zachowku, w szczególności uwzględniające relacje na tle spadkodawca - uprawniony do zachowku, które z istoty wszak są niezmienne - ocena zachowania uprawnionego z tytułu zachowku po śmierci spadkobiercy nie ma wpływu na ocenę tego rodzaju przeszłych zdarzeń. Przy tym, jak widać, chodzi tu o inne jakościowo kategorie sytuacji, niż wskazane w części niniejszego artykułu, do której odnosi się przyp. 23.

30 Dlatego też ten przykład z orzecznictwa, nawet przy przyjęciu generalnej tezy, że rozstrzygnięcie oparte na art. 5 k.c. może mieć skutki definitywne, budzi wątpliwości co do jego poprawności o tyle, że tam odwołanie do art. 5 
zachowania uprawnionego względem innej osoby w przeszłości, która to ocena ujmowana jest czysto retrospektywnie, a dokonując oceny abstrahuje się całkowicie od sytuacji teraźniejszej lub przyszłej. W zasadzie można by powiedzieć, że chodzi o takie okoliczności, nawet jeśli przy powołaniu się na nie składa się deklaracje o niepozbawieniu w ten sposób czyjegoś uprawnienia, do których odwołanie się powoduje skutek polegający na faktycznej ${ }^{31}$ modyfikacji uprawnienia (a nawet jego faktycznej utracie). Nie można takiej sytuacji zrównywać z sytuacją, której skutki są faktycznie trwałe, jednak choćby hipotetycznie mogą ulec zmianie - jak w analizowanym w piśmiennictwie przypadku nieuwzględnienia roszczenia windykacyjnego skierowanego przeciwko osobie niepełnosprawnej, która dostosowała, niebędący jej własnością lokal do swoich potrzeb. ${ }^{32} \mathrm{~W}$ istocie, skutek zastosowania konstrukcji nadużycia prawa może mieć wówczas faktycznie trwały charakter. Gdyby jednak (co może być stosunkowo mało prawdopodobne, ale choćby w niewielkim stopniu możliwe) osoba ta uzyskała (np. w drodze dziedziczenia) środki pozwalające jej zaspokoić swoje potrzeby mieszkaniowe w inny sposób, odpada potrzeba jej ochrony na podstawie art. 5 k.c. Jak widać, jest to sytuacja jakościowo odmienna niż wynikająca ze wskazywanych przez R. Trzaskowskiego judykatów Sądu Najwyższego. Nie można też przeoczyć, co jednak nie jest wielkim zaskoczeniem, że w orzecznictwie Sądu Najwyższego odnajdziemy wypowiedzi negujące wprost tezę o możliwości z góry trwałego ukształtowania sytuacji podmiotów prawa na podstawie art. 5 k.c. Otóż w przywoływanym przez M. Pyziak-Szafnicką wyroku SN z dnia 11 września 1961 r. ${ }^{33}$ wprost stwierdza się, że niemożliwe byłoby oddalenie powództwa windykacyjnego na podstawie art. 3 p.o.p.c. (obecnie: art. 5 k.c.), jeśli właściciel nie mógłby w przyszłości ponowić swego żądania. Trzeba mieć jednak na uwadze, że rozstrzygnięcie to dotyczyło bezpośrednio problematyki ochrony własności, zaś ustalenia dotyczące trwałego skutku zarzutu nadużycia prawa poczynione przez R. Trzaskowskiego dotyczą w szczególności roszczeń pieniężnych. ${ }^{34}$

k.c. nie jest, ściśle rzecz ujmując wynikiem oceny okoliczności konkretnego przypadku, ale aspektu o charakterze mocno abstrakcyjnym. Stąd próba osiągnięcia zamierzonego przez Sąd Najwyższy efektu powinna być podjęta w drodze wykładni odpowiednich przepisów prawa, a nie stosowania art. 5 k.c., nie przesądzając jednak trafności wyniku interpretacji. Por. T. Justyński, Glosa do wyroku z dnia 15.02.2002 r., V CA 2/02 („Orzecznictwo Sądów Polskich” 2003, nr 6, s. 332 i n.), Z. Truszkiewicz, Użytkowanie wieczyste. Zagadnienia konstrukcyjne, Kraków 2006, s. 224, przyp. 107.

31 Bo w sensie prawnym nie powoduje formalnej utraty prawa podmiotowego, jakkolwiek skutek gospodarczy jest w istocie tożsamy.

32 Tak, powołując się na niepublikowany Wyrok Sądu Najwyższego z dnia 10.12.1993 r., sygn. I CRN 200/93, K. Pietrzykowski, (w:) Kodeks cywilny. Komentarz, t. 1, s. 49; W. Borysiak, Ochrona własności..., op. cit., s. 36, przyp. 99, zob. też R. Trzaskowski, Skutki sprzeczności..., op. cit., s. 480, przyp. 1513.

33 Sygn. I CR 693/61, OSNCP 1963,nr 2, poz. 31, zob. M. Pyziak-Szafnicka, (w:) System prawa prywatnego. Prawo cywilne - część ogólna, t. 1, Warszawa 2007, s. 823; eadem, komentarz do art. 5 k.c., teza 65, (w:) Kodeks cywilny. Część ogólna. Komentarz, pod red. M. Pyziak-Szafnickiej, Lex 2009 (wersja elektroniczna).

34 R. Trzaskowski, Skutki sprzeczności..., op. cit., s. 482 i przywołany tam (w przyp. 1519) wyrok Sądu Najwyższego z dnia 13.04.2005 r., sygn. IV CK 663/04, Lex nr 284687. Można zauważyć w doktrynie tendencję do nieco odmiennego traktowania na tle art. 5 k.c. uprawnień tworzących prawo własności oraz innych uprawnień, w szczególności wynikających ze stosunków zobowiązaniowych; por. M. Pyziak-Szafnicka, (w:) System prawa prywatnego, op. cit., s. 823 . 
Jednym $\mathrm{z}$ bardziej istotnych zagadnień poruszanych w orzecznictwie sądowym ściśle związanym z prowizorycznym i definitywnym skutkiem działania $\mathrm{w}$ warunkach nadużycia prawa podmiotowego jest kwestia dopuszczalności redukcji bądź całkowitego pozbawienia prawa do zachowku na podstawie art. 5 k.c. Ma ona sporą doniosłość praktyczną, przy tym obrosła niebagatelną liczbą orzeczeń; również w doktrynie poświęcono jej uwagę. Dlatego właśnie owo zagadnienie posłuży za przedmiot dalszych rozważań $\mathrm{w}$ kontekście trwałości skutku podniesienia zarzutu nadużycia prawa.

Jak powszechnie wiadomo, w judykaturze Sądu Najwyższego podstawowe znaczenie w kwestii ustalenia skutków zastosowania art. 5 k.c. do roszczenia o zachowek ma wyrok z dnia 19 maja 1981 r., ${ }^{35}$ którego teza ma brzmienie: „W sprawie o zachowek nie jest wyłączone obniżenie wysokości należnej z tego tytułu sumy na podstawie art. 5 k.c.”. W jego uzasadnieniu zawarto stwierdzenie, że jeśli zasadniczym składnikiem spadku jest spółdzielcze prawo do lokalu mieszkalnego czy też prawo własności nieruchomości służącej do zaspokajania potrzeb mieszkaniowych zobowiązanego do zapłaty zachowku, które to potrzeby nie mogą zostać zaspokojone w inny sposób i przy tym inne składniki spadku nie wystarczą do zaspokojenia roszczeń z tytułu zachowku - wówczas, uwzględniając sytuację osobistą i majątkową uprawnionego i zobowiązanego może dojść do redukcji kwoty należnej tytułem zachowku. Teza o możliwości obniżenia kwoty należnej z tytułu zachowku znalazła akceptację również w wyroku Sądu Najwyższego z dnia 7 kwietnia 2004 r. ${ }^{36}$ w którym, odwołując się do ww. wyroku z dnia 19 maja 1981 r. zawarto myśl: „Dokonując osądu roszczenia o zachowek w tym aspekcie trzeba przy tym mieć na uwadze, że prawa uprawnionego do zachowku przysługujące mu ze względu na szczególny, bardzo bliski stosunek rodzinny, istniejący między nim a spadkodawcą, służą urzeczywistnieniu obowiązków moralnych, jakie spadkodawca ma względem swoich najbliższych oraz realizacji zasady, iż nikt nie może na wypadek swojej śmierci rozporządzić swoim majątkiem zupełnie dobrowolnie, z pominięciem swoich najbliższych.” Dodać trzeba, że w postanowieniu z dnia 11 lipca 2012 r. ${ }^{37}$ Sąd Najwyższy uznał, że na podstawie art. 5 k.c. jest też, w świetle dotychczasowego orzecznictwa Sądu Najwyższego, możliwe całkowite pozbawienie prawa do zachowku.

Teza o możliwości korektury w zakresie stosowania przepisów o zachowku na podstawie art. 5 k.c. znalazła uznanie Trybunału Konstytucyjnego, który w wyroku z dnia 25 lipca $2013 \mathrm{r}^{38}$ aprobująco przedstawił ten kierunek stosowania art. 5 k.c.

\footnotetext{
35 Sygn. III CZP 18/81, OSNCP $1981 \mathrm{nr}$ 12, poz. 228.

36 Sygn. IV CK 215/03, LEX nr 152889.

37 I CSK 75/12, Lex nr 1311040 z krytyczną glosą M. Trzebiatowskiego (M. Trzebiatowski, Artykuł 5 k.c. versus art. 991 § 1 k.c., czyli o dopuszczalności całkowitego pozbawienia prawa do zachowku z powodu postawy moralnej uprawnionego względem zobowiązanego, „Glosa” 2013, nr 2, s. 82 i n.). 
W literaturze prawniczej silnie reprezentowane jest stanowisko wspierające ów nurt orzecznictwa Sądu Najwyższego. ${ }^{39}$ Nie sposób jednak nie zwrócić uwagi na głosy negujące jego prawidłowość. W szczególności, należy zwrócić uwagę na głos T. Justyńskiego, który odwołując się do podstawowych zasad stosowania art. 5 k.c. podniósł, iż definitywne obniżenie wysokości zachowku na podstawie art. 5 k.c. prowadziłoby do utraty prawa podmiotowego w zakresie równym obniżeniu, a więc mielibyśmy do czynienia $\mathrm{z}$ założenia $\mathrm{z}$ definitywnym skutkiem zastosowania tego przepisu. ${ }^{40}$ Tymczasem, zastosowanie art. 5 k.c. jest tu wprawdzie dopuszczalne, ale respektując regułę tymczasowości skutków wyroku opartego na art. 5 k.c., a więc uwzględniając możliwość wystąpienia z roszczeniem o uzupełnienie obniżonej kwoty zachowku w razie późniejszej zmiany okoliczności towarzyszących nadużyciu prawa podmiotowego. ${ }^{41}$ Poglądy T. Justyńskiego w tej materii zasadniczo podziela P. Księżak, który jednak uznaje możliwość definitywnego skutku zastosowania art. 5 k.c. w zupełnie ekstremalnych przypadkach, jak np. wystąpienie z roszczeniem o zachowek przez zabójcę spadkodawcy, a więc ,ze względu na wyjątkowy splot zdarzeń czy szczególnie rażące okoliczności sprawy poprzestanie na spójnym konstrukcyjnie rozwiązaniu nie może być wystarczające ze względu na momenty społeczne i aksjologiczne". ${ }^{42}$ Pogląd ten skłania do wyrażenia następujących uwag. Przede wszystkim (jakkolwiek jest to specyfika pojęć niedookreślonych i w związku z tym w żadnym razie uwagi tej nie można traktować jako zarzutu pod adresem Autora) nigdy nie będzie możliwe określenie ścisłej granicy między takimi ekstremalnymi przypadkami a przypadkami mniejszej rangi, w tym „rażącymi” czy też, jak nawet ujmuje się to w niektórych judykatach „szczególnie rażącymi” (którego to zwrotu nota bene używa również Autor) i nieraz będziemy mieli do czynienia z wątpliwościami, czy dany przypadek podpada pod zakres zastosowania art. 5 k.c. W orzecznictwie sądowym na tle aktualnej praktyki stosowania art. 5 k.c. do roszczeń o zachowek przyjmuje się, że można go zastosować w przypadkach rzeczywiście wyjątkowych - Autorowi chodzi zaś, jak należy sądzić, ${ }^{43}$ o ścieśnienie i tak restryktywnie charakteryzowanych przypadków podpadających pod trwały zakres oddziaływania art. 5 k.c. w stosunku do obecnej praktyki orzeczniczej. Warszawa 2013, s. 909; J. Kremis, (w:) Kodeks cywilny. Komentarz, pod red. E. Gniewka i P. Machnikowskiego, s. 1681; B. Kordasiewicz, J.S. Piątowski, Prawo spadkowe. Zarys wykładu, Warszawa 2011, s. 221 (por. jednak ostrożne stanowisko B. Kordasiewicza, (w:) System prawa prywatnego. Prawo spadkowe, t. 10, Warszawa 2013, s. 954), jak się wydaje również E. Niezbecka, komentarz do art. 991 k.c., teza 19, (w:) Kodeks cywilny. Komentarz. Tom IV. Spadki, pod red. A. Kidyby, Lex - wersja elektroniczna; A. Zbiegień-Turzańska, (w:) Kodeks cywilny..., op. cit., s. 325.

40 T. Justyński, Glosa do wyroku SN z dnia 7 kwietnia 2004 r., IV CK 215/03, „Państwo i Prawo” 2005, nr 6, s. 113.

41 Zarzut o niezgodności rozstrzygnięcia Sądu Najwyższego w wyroku z dnia 19.05.1981 r. z założeniami konstrukcyjnymi dotyczącymi zastosowania art. 5 k.c. sformułował wcześniej Z. Truszkiewicz; zob. tegoż, Zachowek ze spadku obejmującego gospodarstwo rolne, Kraków 1993, s. 113.

42 P. Księżak, Zachowek w polskim prawie spadkowym, Warszawa 2012, s. 376.

43 Mimo że sam posługuje się w tym kontekście już obecnym w bieżącym orzecznictwie zwrotem „szczególnie rażące przypadki”. 
W związku ze stosowaniem art. 5 k.c. w kontekście wysokości zachowku, należy zwrócić jeszcze uwagę na zagadnienie budzące rozbieżności w orzecznictwie i doktrynie, a mianowicie, czy zdarzenia mające uzasadniać sięgnięcie do tej regulacji muszą zachodzić jedynie na linii uprawniony do zachowku - spadkobierca, czy też można brać pod uwagę okoliczności zachodzące na linii spadkodawca - uprawniony do zachowku. Pierwszy wariant jest preferowany przez T. Justyńskiego, który podaje dwa argumenty świadczące o trafności jego stanowiska. Po pierwsze, relacje spadkodawca - uprawniony są istotne z perspektywy regulacji instytucji, którą jest wydziedziczenie, po drugie zaś, co istotniejsze, uwzględnienie relacji spadkodawca - uprawniony prowadziłoby do powstania sprzecznych z konstrukcją art. 5 k.c. trwałych skutków. ${ }^{44} \mathrm{Z}$ kolei za możliwością uwzględniania zdarzeń zachodzących na linii spadkodawca - uprawniony w interesującej nas materii opowiada się wprost A. Zbiegień-Turzańska. ${ }^{45}$

Orzecznictwo sądowe nie jest także, jak wzmiankowano, spójne w tej kwestii. Za uwzględnieniem przy ocenie stopnia redukcji wysokości zachowku wypowiedział się przykładowo Sąd Apelacyjny w Szczecinie z dnia 7 listopada 2012 r. oraz Sąd Apelacyjny w Łodzi w wyroku z dnia 9 kwietnia 2013 r. Rozważał taką ewentualność, mimo że nie zastosował art. 5 k.c. (skąd jednak należy wnioskować, że dopuszczał jako przesłanki obniżenia zachowku zdarzenia na linii spadkodawca - uprawniony) Sąd Apelacyjny w Warszawie w wyroku z dnia 18 stycznia 2013 r. oraz Sąd Apelacyjny w Krakowie w wyroku z dnia 5 grudnia 2012 r. ${ }^{46}$

Odmiennie, za uwzględnieniem $w$ kontekście obniżenia kwoty zachowku jedynie relacji między uprawnionym a spadkobiercą opowiedział się Sąd Apelacyjny w Warszawie w wyroku z dnia 6 marca 2013 r., ${ }^{47}$ Sąd Apelacyjny w Poznaniu w wyroku z dnia 15 lutego 2012 r. $^{48}$ czy Sąd Apelacyjny w Białymstoku w wyroku z dnia 23 kwietnia $2014 \mathrm{r}^{49}$

Nie wydaje się, aby można było pominąc relacje pomiędzy spadkodawcą a uprawnionym - jeśli, jak czynią to powszechnie sądy orzekające w sprawach o zachowek - zakłada się trwały skutek orzeczenia dotyczącego wysokości zachowku wydanego z uwzględnieniem art. 5 k.c. Otóż głównym argumentem świadczącym przeciwko uwzględnieniu tej relacji i ograniczeniu się do badania stosunków między uprawnionym i spadkobiercą ma być wyłącznie prowizoryczny skutek zastosowania konstrukcji nadużycia prawa. W kontekście praktyki sądów nie respektującej tego założenia teoretycznego, ale odwołującej się tu do jej implikacji, można więc nawet rzec, że odmowa uwzględnienia relacji między spadkodawcą i uprawnionym jest niekonsekwentna i niespójna na gruncie założeń faktycznie towarzyszących stoso-

T. Justyński, Glosa do wyroku SN z dnia 7 kwietnia 2004 r..., op. cit., s. 114-115.

A. Zbiegień-Turzańska, (w:) Kodeks cywilny. Komentarz, pod red. K. Osajdy, s. 325.

Sygn. I ACa 1143/12, Lex nr 1289766

Sygn. I ACa 1132/12, Lex nr 1316297

Sygn. I ACa 1121/11, Lex nr 1133334

Sygn. I ACa 692/13, Lex nr 1461014 
waniu art. 5 k.c. Ponadto należałoby się zastanowić, czy nie stoi w opozycji do społecznego poczucia słuszności.

Podsumowując prowadzone w niniejszym artykule rozważania należy wskazać na następujące kwestie. Rozwiązanie polegające na akceptacji wystąpienia z góry trwałego skutku wywołanego przez podniesienie zarzutu nadużycia prawa niewątpliwie jest odstępstwem od ściśle ujmowanego założenia o tymczasowym skutku wywoływanym przez regulację art. 5 k.c. $Z$ drugiej zaś wydaje się, że rozwiązanie to może prowadzić do osiągnięcia rezultatów odpowiadających rzeczywistej potrzebie społecznej, które zaspokajają, czynią zadość społecznemu poczuciu słuszności - oczywiście w zupełnie wyjątkowych przypadkach. Stąd nie wydaje się zasadne całkowite odrzucanie a priori widocznych w doktrynie i orzecznictwie tendencji do uwzględnienia tego rodzaju skutków na gruncie art. 5 k.c. Jak trafnie przyjął P. Księżak na tle instytucji zachowku, są sytuacje, gdy „,czystość konstrukcji musi ugiąć się pod ciężarem okoliczności faktycznych". ${ }^{50}$ Istotne jest, aby pomijając takie wyjątkowe odstępstwo, w pozostałym zakresie zachować jednak w możliwie najwyższym stopniu zasady stosowania art. 5 k.c. Oczywiście taka propozycja może być łatwo skontrowana przez zarzut, że kryje się tu zagrożenie uczynienia z regulacji nadużycia prawa wytrychu dla dowolnych rozstrzygnięć nie poddających się sensownej weryfikacji, a także, że na tle art. 5 k.c. nie ma miejsca na odstępstwa od ściśle sformułowanych zasad z powodu braku podstaw normatywnych dla takiego zabiegu. Nie sposób uznać tak po prostu, aby zarzuty takie były bezzasadne. Jednak momenty napięcia między wymogami słuszności i restryktywnym ujęciem litery prawa są chyba z istoty wpisane w kontekst oddziaływania regulacji prawnych.

50 P. Księżak, Zachowek..., op. cit., s. 376. 


\section{NOTES ON TEMPORARY AND DEFINITIVE EFFECTS OF THE APPLICATION OF THE LEGAL CONSTRUCTION OF THE CONCEPT OF ABUSE OF SUBSTANTIVE RIGHT (EXERCISING THE RIGHT IN A MANNER THAT UNDERMINES THE PRINCIPLES OF EQUITY)}

The legal construction of the aspect of abuse of substantive right is one of the most important manifestations of equitable principles in civil law. Article 5 of the Civil Code, which contains the aforementioned regulation, may be applied together with the doctrine and case law principles, such as: prohibition on the acquisition and loss of substantive right, based on such acquisition; the defensive nature of the allegation of abuse of rights; or the rule of temporary effect of the condition of abuse of rights. The latter, according to the most dominant view, means that the substantive right may be exercised after the cessation of the circumstances justifying the allegation of abuse of rights. However, in exceptional cases, this does not preclude the occurrence of a permanent condition, which is equivalent to the actual loss of rights. A particularly important example of a permanent effect of the condition of abuse of rights is the possibility, widely accepted in the jurisprudence and part of the doctrine, of reducing the amount of legitimate portion due to the entitled party on the basis of Article 5 of the Civil Code.

Keywords: abuse of rights, loss of substantive right, reduction of legitimate portion, equitable principles, principles of social coexistence 